\title{
Repainting, modifying, smashing Taylorism
}

\author{
Hans Pruijt \\ Erasmus University Rotterdam \\ pruijt@fsw.eur.nl \\ Preprint. \\ Published in Journal of Organizational Change Management, 2000, vol. 13, Nr. 5, \\ 439-451
}

\begin{abstract}
Survey data show that post-Tayloristic production concepts are not developing to the extent that many researchers had originally expected. It also is inadequate to portray post-Taylorism as a development that is happening, but just slower than expected. This is inadequate because there are counter tendencies: the resurgence of the assembly line in the highly paradigmatic automobile assembly, the rise of the McDonalds-type organization and continuing skills-replacing automation.

The paper sets out to explain this persistence. First it considers possible reasons for decision-makers to be attracted to Taylorism. Then it turns to reasons for disliking Taylorism. To some extent, it is possible for managers to work around these problems; however there are more ways to tackle these problems by making modifications to Tayloristic patterns, while keeping basic principles intact. So the adaptability is an important explanation for the resilience of Taylorism. Finally the paper makes inferences from results obtained in organizations where a more radical break with Taylorism was attempted.
\end{abstract}

\section{Introduction}

If we wish to have a bearing on where the organization of work is headed, it is vital to consider the development of Taylorism. Is it being superseded by a new paradigm or is it being modified? Is it possible to find an underlying logic in the development of Taylorism? Can one locate agency in the change process or do we have to stick with a contingency approach?

An analysis of Taylorism can hardly proceed without a definition since interpretations of Taylorism tend to vary. The central feature of Taylorism is the separation of conception from execution. Managers achieve this by applying three principles. The first principle of "scientific management" as Taylor called it, is the decoupling of the labor process from the skills of the workers: "The managers assume [..] the burden of gathering together all of the traditional knowledge which in the past has been possessed by the workmen and then of classifying, tabulating, and reducing this knowledge to rules, laws, and formulae" (in Braverman 1974: 112).

The second principle is: "All possible brain work should be removed from the shop and centered in the planning or laying-out department" (in Braverman 1974: 113).

The third principle is, that management should not leave it to the workers to decide how they go about their tasks. Instead, management should prescribe exactly how, and how fast, the tasks must be performed. The context in which these principles are located is logistical streamlining and standardization of components.

Taylorism is a refinement of the management strategy of detailed division of labor. It is important to draw a sharp distinction between detailed division of labor and specialization. Through specialization, people can develop themselves further in their crafts or professions; whereas detailed division of labor reduces people to performers 
of routine tasks. Detailed division of labor entails analyzing a production process and breaking it down into a multitude of tasks performed by different workers. In this way, a craft-based labor process that was once controlled by the workers themselves falls to pieces. Then, managers put the pieces together to create a process that is under managements' control. The financial advantage of this strategy is that it becomes possible to hire less well-paid workers. This principle was already clearly stated by Charles Babbage in 1832, the same Charles Babbage who devised the first computer architecture (Braverman 1974: 188). Taylorism tends to carry the detailed division of labor to new extremes, where work cycles are measured in seconds.

Taylorism implies low-trust relations between employer and employees. Therefore direct control is needed to ensure that labor power bought is turned into labor performed. This control question urges managers to find ways of imposing on workers what they should do, in what way, within which limits and at what pace, and to evaluate work performance and apply sanctions. Taylor's prescriptions amounted to reliance on a raft of supervisors, but the Ford Motor Company proved that a mechanically paced assembly line is a more efficient control system. The assembly line functions as a system of technical control, which means that the entire production process or large segments of it are based on a technology that regulates the working pace and controls the labor process (Edwards 1979: 112-113). The assembly line supplants the direct conflict between worker and foreman. Scientific management, as an explicit method, became unfashionable after the 1930s. Its principles, however, continued to have an impact on the design of jobs (Braverman 1974: 119, De Sitter 1981: 21, Schumann et al. 1989: 67, Merkle 1980: 3). A workable concise definition of Taylorism is: management strategies that are based upon the separation of conception from execution.

\section{Taylorism is enduring and resilient}

In 1980s there were signs - at least on paper - that in some sectors Taylorism was coming to an end. Kern and Schumann (1984: 19) reported a rise of "new production concepts" in the core sectors of German industry, the automobile, machine tools and chemical industries. These new production concepts revolve around greater respect for skill and worker involvement. This means that in the core sectors, the polarization between elite and routine workers is disappearing. Product quality, flexibility and enabling technology are given as reasons for this change. Routine workers would become "system regulators". System regulators monitor the actions of automated machinery and intervene when they deviate from their programmed course. Piore and Sabel (1984) claimed that flexible technology and fragmentation of markets would usher in an era of "flexible specialization". However, it seemed that the change process was not universal. Kern and Schumann, for example, specifically excluded the food sector. Later research into the spread of new production concepts showed that - even in those core sectors - change was less than expected, maybe even nonexistent. System regulators remained few, around two to five per cent.

Even in an almost completely (99 per cent) automated production phase, like spot welding in body construction, it turned out that few of the workers had risen to system regulator. 95 per cent of them were still engaged in manual welding and correcting faulty weldings. Only five percent of the workers in the spot welding phase were working as system regulators (Schumann et al. 1989). Huys, Sels and Van Hootegem (1995) could classify only two per cent of the jobs as system regulator jobs. 
A large-scale study on information technology in the European service sector (Child and Loveridge 1990: 360) concluded that banks rarely exploited the new possibilities of broader access to pooled information and knowledge and that "modifications to existing hierarchies are modest". Huys, Sels and Van Hootegem (1995) found that in Belgian car plants, management was pushing towards enhanced predictability and uniformity of actions. A mammoth trend study on rationalization in the German car, chemical and machine tool industries (Schumann et al. 1994: 659, Schumann 1998) concluded that the division between conception and execution proved stronger than had been predicted a decade earlier (in Kern and Schumann 1984). Professionalization was not a sufficient condition for emancipation. Moreover, the study found that a substantial gap remained between direct and indirect sectors, between "new production specialists and specialized specialists".

Studies that emphasize change exist as well. In the UK, Gallie, White et al. (1998: 290-292) were impressed upon finding indications of upskilling. Intrinsic interest in work increased. Employers delegated more responsibility to workers. There was more task discretion. Explanations advanced were new technology, more sophisticated control and new management techniques that implied a shift from control to commitment. However there was "no evidence of an increase in the participation of employees in organizational decision-making" (Gallie, White ea. 1998: 315). Sisson (1996: 27), surveying the state of research on European workplaces concluded that the number with "high performance work systems" was "negligible". Vallas (1999) found that centralization of control and standardization of methods are on the increase. Assessments of the spread of post-Tayloristic production concepts vary, but a safe conclusion seems that Taylorism is, contrary to earlier rumors, very much alive. Moreover, it is inadequate to portray post-Taylorism as a development that is happening, but just slower than expected. This is inadequate because there are counter tendencies. In the automobile industry, there is a resurrection of the assembly line (Schumann et al. 1989, Pruijt 1997: 112, Shimokawa, Jürgens and Fujimoto: 1997, Springer 1999).

This is extra significant because, historically, job design paradigms tend to spread from the car industry: the assembly line from Ford, semi- autonomous teams from Volvo and lean production from Toyota.

The application of pure Taylorism has areas of solid growth, such as the McDonaldstype firm ("McDonaldization"), characterized by predictability and controllability (Ritzer 1993), and call centers. Furthermore, advanced automation can entail the incorporation of human skills and decision making into machinery, and thus the removal of brainwork from the shop floor - a key element of Taylorism.

Thus Taylorism is both enduring and resilient. In the following sections I will consider possible explanations.

\section{Attractions of Taylorism}

There are several points that make Taylorism attractive to managers. Two stand out because they are core elements of Taylor's doctrine, and are not dependent on particular circumstances. A core attraction of Taylorism is that it promises that the best possible method, "the one best way" will be used. Whether there exists a one best way to work may be a matter of philosophical debate. Taylor strongly believed in it. But also in highly modern discussions about organizational learning in the context of mass production we find this assumption. For example, Adler and Cole (1995: 169) write: "Standardization captures best practice and facilitates the diffusion of 
improvement ideas throughout the organization - you cannot diffuse what you have not standardized". In this view, standardization means that, for each task X, the best way is determined and laid down in rules. Everyone who has to perform this task X, must follow the rules for $\mathrm{X}$ exactly.

In the area of software engineering, one finds the same notion in the Capability Maturity Model (CMM) from Carnegie Mellon University's Software Engineering Institute. The CMM consists of a hierarchy of five maturity levels. At the lowest level there is no stable process management. At the second level there is project management and processes are repeatable. At the third level the notion of the one best way comes in. Processes are documented and standardized. In the whole organization, employees follow these processes consistently. The fourth level adds quantification and measurement. The top level entails optimization, continuous improvement (Bach 1994, Montgomery 1995). Japanese "software factories" are prime examples of process standardization in the software industry (Cusumano 1991).

The second core attraction of Taylorism is: it promises to be a means against what Taylor called "systematic soldiering". Although this may look old-fashioned or taboo, this concern is as relevant today as ever. When European managers compare their plants with similar Japanese plants, they often find a productivity gap at their disadvantage (c.f. Pruijt 1997: 108-110). At Daimler-Chrysler in Germany, the current strategy for rationalization was deemed to be too much based on responsible autonomy, while in Japanese plants standard worksheets were important for productivity. These standard worksheets specify the order of operations and the time allowed for them. The reasoning behind this boils down to this: when granted autonomy, workers in mass production do not put in a maximum effort (Springer 1999).

Beside the core attractions of Taylorism there are more contingent ones. Tayloristic control can compensate for a lack of employee motivation. It also allows hiring cheaper workers and tapping into an unskilled labor market. And downsizing is more compatible with a low-trust type of organization than with a high trust type.

Moreover, Taylorism itself creates the conditions for its propagation. As Zuboff (1988) has shown, advanced automation tends to disempower workers to handle unexpected situations, which leads to the necessity of advancing automation even further. Similarly, in organization in which employees are systematically following detailed rules, a likely reaction to imperfections is creating more rules.

The Tayloristic attractions listed above assume rational choice. We should, however, not forget that rationality is not the only driver. For example: information about F. W. Taylor's behavior in his private life shows him as a person who was obsessed with control. This personality trait was already evident in his youth (Kanigel 1997: 104; Morgan 1986:204-207). Ritzer (1993) also noted the irrationality of rationalization.

\section{Modifications of Taylorism and the logic behind these}

There are many reasons for job design decision makers not to like Taylorism. However, there are many opportunities to neutralize these points - allowing pure Taylorism to persist in repainted form, or to modify Taylorism to keep it alive in the face of changing environment conditions, thereby creating Neo-Taylorism.

A few of these drawbacks in particular already hindered Taylor himself. One of these drawbacks is, that Taylorism is expensive because it entails creating jobs for non value adding supervisors and other indirect workers. Taylor wanted to subdivide the 
work that was usually performed by a single gang boss among eight men: route clerks, instruction card clerks, cost and time clerks, gang bosses, speed bosses, inspectors, repair bosses and a shop disciplinarian (Taylor 1911: 104). Taylorism is not just a movement for efficiency by also a movement for providing jobs in the production process for the middle class (Merkle 1980).

In 1901, when the United States Steel Corporation took over the cradle of Taylorism, Bethlehem Steel, it laid off sixty specialized foremen (Kanigel 1997: 355). To Taylor's dismay, the high costs led employers to dilute the model (Bloemen 1988: 41). In the Toyota production system we find a carefully designed modification that deals with this drawback of indirect labor costs while preserving the focus on the one best way. In this system, first level supervisors do double duty: they supervise and work (from time to time) on the line as well. Misleadingly, these supervisors tend sometimes to be called team leaders. In the Toyota production system, the team leader has a fixed position. Management appoints team leaders. The main difference between a Taylorist low level supervisor and a Toyota team leader is that the Toyota team leader has to perform production work himself (Grønning 1992: 135). Job design is firmly rooted in Taylorism. An essential element of the Toyota production system is that for each task there is a "standard work sheet" that contains the cycle time, the order in which the worker must carry out the operations and the standard inventory that belongs to the task (Ohno 1988).

At Toyota, team leaders perform the detailed definition of operations and set the times for these. They do this on the basis of a coarse planning provided by a central department. Team leaders do time studies, and coordinate with leaders of parallel teams.

Paul Adler (with co-authors) describes a further modification of Taylorism along the line of combining production work with industrial engineering (Adler 1992; Adler and Borys 1996; Adler and Cole 1993). When studying "New United Motor Manufacturing, inc" (NUMMI), a U.S. joint venture of Toyota and General Motors, Adler found that production workers themselves were doing work analysis with stopwatches. Apparently this is a special feature of the NUMMI plant. Adler (1992: 37 ) notes that at Toyota, mainly team leaders perform work analysis.

Adler (1992) quotes a NUMMI manager who explains this as a result of a "history of more conflictual relations with supervisors and industrial engineers" compared to Japan. In Japan team leaders can do the work analysis because of the trust placed in them by the workers.

From Adler's paper (1992) one can glean one limitation of the NUMMI system: it is impossible or difficult to increase the time allowed for operations. This poses problems for older workers when times have been set on the basis of the performance of young workers. Adler turned the NUMMI model into a new production concept, "democratic Taylorism". This comprises work analysis by workers, team meetings, kaizen and a heavily promoted suggestion scheme, all combined with strict standardization of work. At Daimler-Chrysler, managers expect this model to supersede responsible autonomy.

A widely noted problem of Taylorism is that it is not conducive to flexibility. There is one exception: Taylorism does boost numerical flexibility: it makes it easy to quickly integrate new workers in a production process, and it allows laying off workers without losing knowledge from the organization. Faced with the need to respond more quickly to varying customer demands, managers might be able to retain large Tayloristic production units for the predictable parts of production, while having 
semi-autonomous teams operating in parallel with this to provide flexible quick response capability. The old Babbage principle remains in force: division of labor makes it possible to hire cheaper workers.

Huys, Sels and Van Hootegem (1995) found that Belgian car plants did acquire the capability for flexible adaptation, but not through discussions among workers. On the contrary, it was sophisticated planning in advance that produced flexibility.

Mass customization is another Tayloristic route to flexibility. Modular construction allows customization based on simplified work. In mass customization, it is possible to use an information system for collecting parts together and for generating customized instructions to workers (Laudon and Laudon 1996: 95).

During Japan's reconstruction, Taiichi Ohno, the designer of the Toyota Production System, faced the challenge of producing a variety of car models within a small production volume. This led to a set of solutions. One still fits within classical Taylorism: perfecting setting up and die change procedures to speed these up dramatically. A second solution entails a modification of Taylorism: letting workers perform a variety of tasks. One worker operates several machines, which may be of different types, simultaneously. The machines have built-in control systems, which means that they can operate partly unattended. Attending a machine is seen as waste, so workers make rounds hopping from one machine to the next (Ohno 1988, 10-11). Job rotation enables workers to learn of broad set of skills. However, these skills are as shallow as possible. In Ohno's (1988: 22) view, machines must be fool proof. It should be possible to learn the correct working procedures within three days.

A related problem of Taylorism is loss of innovative capacity. Solutions for companies to satisfy their innovation needs within the framework of Taylorism are buying up small, innovative companies, or concentrating innovation in a separate department or in a "skunk works". In this way, the jobs of the main work force can remain routine. A problem that is also related to flexibility is the information problem of central planning. Organizations with a high level of central planning suffer the same kind of information difficulties that centrally planned economies have. Tackling this problem while remaining inside Taylorism means avoiding granting autonomy to the shop floor level. Information systems can be used to take care of this. Alternatively, a ban on buffers (i.e. intermediate storage), as advocated in lean production, can increase transparency. Also the kanban system can be seen as a means of decreasing the information processing load at the central level while keeping shop floor autonomy at bay.

Taylorism leads to inherently unattractive work on the shop floor. The resulting lack of motivation may be counteracted by the pay system and by careful selection of workers. Especially when there is near full employment, this is not sufficient. Low unemployment means that employees have the option to avoid degrading jobs. In the 1960s for instance, when there was full employment in the Netherlands, Philips faced high turnover rates for assembly line workers. This prompted Philips to start experimental reforms that in some cases developed into team working (Teulings 1977: 220). This phenomenon disappeared as unemployment soared in the 1970s. In Sweden, however, full employment remained throughout the 1970s and the 1980s. There, the unemployment figure for 1970 was 1.5 per cent. For 1986, it was 2.7 per cent. Labor turnover, absenteeism and recruitment difficulties led Volvo management to search for alternatives for the assembly line in car production. In the early 1990s, 
recruitment problems prompted Japanese car companies to introduce reforms (Benders 1996).

One stumbling block that is manifest from the beginning of Taylorism is that it clashes with democratic values, especially with autonomy. In Western societies, loss of autonomy is not a desirable vision. In managerial discourse, the clash between Taylorism and autonomy gives rise to a language game in which the meaning of autonomy is emptied out. Thus, Womack, Jones et al. (1990: 14), while describing a production system that is (according to the information that they provide themselves) based on assembly lines and in which work cycles are around one minute, assert that "most people - including so-called blue-collar workers - will find their jobs more challenging as lean production spreads" and that "lean production calls for learning far more professional skills and applying these creatively in a team setting rather than in a rigid hierarchy". "Management stresses that problem-solving is the most important aspect of any job" (Womack, Jones et al. 1990: 199).

When promoting business process reengineering, Hammer and Champy advocate Tayloristic solutions such as the use of knowledge based information systems to replace "highly trained" specialists with "generalists" (Hammer and Champy 1994: 38), "triage" (i.e. splitting off difficult cases and assigning these to specialists) or in a decentralized organization, using centralized computer controls. Nevertheless, they claim that: "Instead of separating decision-making from real work, decision-making becomes part of the work. Workers themselves now do that portion of a job that, formerly, managers produced" (Hammer and Champy 1994: 53). They say that work becomes "more rewarding since people's jobs have a greater component of growth and learning" (Hammer and Champy 1994: 69). And they tell us that "Companies that have reengineered don't want employees who can follow rules; they want people who will make up their own rules" (Hammer and Champy 1994: 70).

Taylorism is a formalized, bureaucratic system. As such, it provides subordinates a form of protection against arbitrary control. This was a reason why some unions accepted the system in the $1920 \mathrm{~s}$.

There are also paradoxes attached to bureaucratic power. Full specification of tasks and promotions that are governed by rules reduce the power edge of supervisors (Crozier 1964: 187-189). As long as subordinates stick to the rules noting can happen to them; the rules always give some leeway. Progressive bureaucratization increases this leeway. Crozier points out that "the power to make decisions and to interpret and complete the rules, as well as the power to change the rules or to institute new ones, will tend to grow farther and farther away from the field where those rules will be carried out" (Crozier 1964: 189).

The more predictable the system becomes, the more powerful become those who control a source of uncertainty (Crozier 1964: 192). And in a fully bureaucratized system, the subordinates are considerable sources of uncertainty.

In accounts of the Japanese organization of production we find indications that Taylorism is modified by injecting uncertainty at the supervisor level. Dohse, Jürgens and Malsch (1985: 141) describe this form of organization as "the practice of the organizational principles of Fordism under conditions in which management prerogatives are largely unlimited." This reflects in the Japanese notion of competitiveness. Competitiveness means permanent rationalization even at economically good times and flexible, vague working arrangements without precedent-setting agreements (Grønning 1992: 3). This involves Taichi Ohno’s “Oh! 
No!" method in which workloads are calculated at 100-110 per cent. This makes overtime a structural requirement. Through kaizen this overtime is reduced. Subsequently managers increase workloads (Grønning 1992: 27).

In the Japanese system, one finds that bonuses represent a large proportion of the wage packet (up to 50 per cent). Individual bonuses are based on assessments by supervisors on how deeply a worker cooperates in the system. Group bonuses are also given (Cf. Dohse, Jürgens and Malsch 1985 137-138). Workers have to compete for better jobs and job boundaries are relatively permeable (Burawoy 1999).

There are many reasons why Taylorism might not appeal to managers: supervision cost, lack of flexibility, loss of creativity, central information processing overload, unattractive work on the shop floor, a clash with democratic values, bureaucratization. However, there are ways to deal with all these points without giving up the central characteristics of Taylorism. This adaptability helps explain the endurance of Taylorism.

\section{Smashing Taylorism}

Supervision cost, lack of flexibility, loss of creativity, central information processing overload, unattractive work on the shop floor, a clash with democratic values and bureaucratization can also be reasons to develop an alternative to Taylorism. When we explore these, we enter the realm of anti-Taylorism.

Anti-Taylorism involves consciously moving towards job enrichment instead of division of labor and towards a reduction of the separation of conception and execution. It also means choosing to use human skills instead of trying to incorporate these into information systems. It further entails striving towards worker autonomy and codetermination instead of increasing discipline.

Anti-Taylorism does not necessarily mean putting the quality of working life before productivity. Anti-Taylorism takes improvement of the quality of working life as a condition for improvement of performance. In contrast, neo-Taylorism takes improvement of the quality of working life as a possible side-effect of the improvement of performance.

What does anti-Taylorism look like, and does it work? These questions were addressed in a study of 150 cases of initiatives to achieve an organization of work that breaks with the Tayloristic pattern (Pruijt 1997). Results can be summarized as follows:

Deliberate policies directed against low-trust employment relations exist. In some organizations, innovative managers, staff personnel and union groups are creating alternatives. Examples are decoupling workers from the assembly line, setting up semi-autonomous teams, sometimes with rotating team leadership and decentralization of detail planning to the shop floor. The innovators receive support from researchers who, combining consultancy and research, accumulate expertise on changing working life and feed this back into organizations. National unions have supplemented their bread-and-butter activities with involvement in the organization of work. So did politicians, who, in several countries, pressed for working life legislation that covers work organization as much as health and safety. And in Scandinavia and Germany, there are state-sponsored research and development programs that explore alternative forms of organization. These programs include efforts to develop technologies that could support change in organizations.

This counter movement was in part driven by recruitment and turnover problems. However, it survived when unemployment rose. Attaining flexibility was a continuing 
motive, but also the unease and stress, both for employees and managers, that comes with low-trust employment relations. An analysis of 150 cases based in Scandinavia, the UK, the Netherlands and Germany showed that it is possible, with monumental effort and a lot of ingenuity, to achieve real change on the shop floor level.

Leaving autonomy on the shop floor level implies that there is no enforcement of a one best way. There will be variation between teams in the way of working. An example is the IHC shipyard in the Netherlands. A change program involved the creation of semi-autonomous teams. Teams had to choose coordinators and the idea was that all tasks should be performed by all team members. Special training courses were part of the program.

One of the teams in the IHC machine factory chose not to have any coordinators, they were happy when they got rid of their bosses. They did not participate in the courses either. They also disregarded the official line of diminishing the division of labor: they kept a special person around who does nothing but removing burrs. Management accepted this, since the team's performance was on a par with the other team in the same workshop that did participate in all aspects of the change program.

The change efforts produced economically viable solutions in the following areas: alleviation of technical discipline (for example by decoupling workers from the pace dictated by an assembly line) and job enrichment (often supported by a skill-based pay system). To production work, tasks were added as quality control, maintenance, setting and programming machines, administration, logistics and contact with customers. A further area of change is decentralization of responsibility. This entails changes such as: previously a planning department would issue a production schedule for each day, in the new way of working teams get assigned a workload for a week. It is now up to the team to perform the detail planning.

We also see that operatives get the authority to call in a technician when something goes wrong; traditionally in production organizations only supervisors may do this.

Notwithstanding the successes, a notable proportion of the organizations later regressed to a more Tayloristic pattern. This happened to several organizations that in the literature have become known as successful innovators.

Regression can be the result of tensions developing within semi-autonomous teams in which there is a rotation team leadership. Team leaders can refrain from taking unpopular decisions, because of the risk of revenge when someone else is team leader. Apart from this there is a substantial chance that within teams a Tayloristic structure crystallizes. More assertive team members start dominating and make sure that less assertive team members do the less attractive routine tasks. Here we see a paradox: decentralization of responsibility gives workers the opportunity to organize the work by themselves in a Tayloristic fashion.

It also happens, that the new structures disappear when central champions of the change programs - managers or trade union activists - leave the firm.

The diffusion of successful alternatives was a weak point as well.

\section{Conclusions and discussion}

Taylorism persists because its attractions are relevant in large sectors of the economy. Irrational factors (anality) play a role as well. Moreover, Taylorism is very adaptable. Breaking away from Taylorism is possible, but it requires a lot of energy. It is now a 
matter of unorganized struggle; it is worthwhile to pursue alliances between change oriented managers and worker representatives on the one hand, and researchers on the other hand. There may be extreme cases where (neo)-Taylorism is unbeatable, for example in the most routinized parts of mass production. On the other hand, there may be areas where anti-Taylorism is the automatic choice. However, such a distinction is never clear-cut, it remains open to contestation and experimentation.

References

Adler, P. S. . 1992. "The 'Learning Bureaucracy': New United Motor Manufacturing Inc ." in Research on Industrial Behaviour, edited by B. M. Staw and L. L. Cummings. Greenwich CT: JAI Press.

Adler, P. S, and Bryan Borys. 1996. "Two types of bureaucracy: Enabling and coercive." Administrative Science Quarterly 41:61.

Adler, P. S., and Robert E. Cole. 1993. "Designed for Learning: A Tale of Two Auto Plants." Sloan Management Review 34:85-94.

Adler, P.S., and R. E. Cole. 1995. "Designed for learning: A tale of two auto plants." Pp. 157-177 in Enriching Production. Perspective on Volvo's Uddevalla plan as an alternative to lean production, edited by A Sandberg. Aldershot: Avebury.

Bach, J. (1994). "The Immaturity of the CMM." American Programmer, September, http://www.stlabs.com/CMM_AP1.HTM

Benders, J. 1996. "Leaving Lean? Recent Changes in the Production Organization of some Japanese Car Plants ." Pp. 9-38 in Economic and Industrial Democracy .

Bloemen, E. 1988. Scientific management in Nederland, 1900-1930. Leiden: Phd. dissertation.

Braverman, H. 1974. Labor and Monopoly Capital: The Degradation of Work in the Twentieth Century. New York: Monthly Review Press.

Burawoy, M. 1999. "Flight from Capitalism." in Szelényi 60, a Festschrift in honor of Iván Szelényi. http://hi.rutgers.edu/szelenyi60/: The Rutgers Institute for Hungarian Studies.

Child, J., and R. Loveridge. 1990. Information Technology in European Services: Towards a Microelectronic Future . Oxford: Basil Blackwell.

Crozier, Michel. 1964. The bureaucratic phenomenon. Chicago: The University of Chicago Press.

Cusumano, M. A. 1991. Japan's Software Factories: A Challenge to U.S. Management. New York Oxford: Oxford University Press.

Dohse, K, U Jürgens, and T Malsch. 1985. "From "Fordism to Toyotism"? The Social Organization of the Labor Process in the Japanese Automobile Industry." Politics and Society 14:115-146.

Edwards, R. C. . 1979. Contested Terrain, New York: Basic Books. .

Gallie, D., M. White, Y. Cheng, and M. Tomlinson. 1998. Restructuring the employment relationship. Oxford: Clarendon Press.

Grønning, T. 1992. "Human Value and "Competitiveness": On the Social Organization of Production at Toyota Motor Corporation and New United Motor Manufacturing, Inc." in Graduate School of Sociology. Kyoto: Ritsumeikan University.

Hammer, M, and J. Champy. 1994. Reengineering the Corporation. A Manifesto for Business Revolution. New York: HarperCollins. 
Huys, R., L. Sels, and G. van Hootegem. 1995. De Uitgestelde Transformatie: Technische en sociaal-organisatorische herstructureringen in de chemische, de automobiel en de machinebouwindustrie . Brussel: Federale Diensten voor wetenschappelijke, technische en culturele aangelegenheden .

Kanigel, R. 1997. The one best way. Frederick Winslow Taylor and the enigma of efficiency. New York: Viking.

Kern, H., and M. Schumann. 1984. Das Ende der Arbeitsteilung? Rationalisierung in der industriellen Produktion. München: Beck.

Laudon, K. C. and J. P. Laudon. 1996. Management Information Systems. Organization and Technology. Upper Saddle River: Prentice-Hall.

Merkle, J. A. . 1980. Management and Ideology: The Legacy of the International Scientific Management Movement. Berkeley CA: University of California Press.

Montgomery, J. (1995). "Make quality Job 1". Byte. 20: 54.

Morgan, G. 1986. Images of Organization. London: Sage.

Ohno, T. 1988. Toyota Production System. Beyond Large-Scale Production. Cambridge USA: Productivity Press.

Piore, M., and C. Sabel. 1984. The Second Industrial Divide, Possibilities for Prosperity. New York: Basic Books.

Pruijt, H. 1997. Job Design and Technology. Taylorism vs. Anti-Taylorism. London: Routledge.

Ritzer, G. 1993. The McDonaldization of Society: An Investigation into the Changing Character of Contemporary Social Life. Thousand Oaks CA: Pine Forge Press.

Shimokawa, K., U. Jürgens, and T. Fujimoto (Eds.). 1997. Transforming Automobile Assembly - Experience in Automation and Work Organization. BerlinHeidelberg-New York: Springer Verlag.

Schumann, M., V. Baethge-Kinsky, M. Kuhlmann, C. Kurz, and U. Neumann. 1994. Trendreport Rationalisierung: Automobilindustrie, Werkzeugmaschinenbau, Chemische Industrie. Berlin: Sigma.

Schumann, M., V. Baethge-Kinsky, U. Neumann, and R. Springer. 1989. Breite Diffusion der Neuen Produktionskonzepte: zögerlicher Wandel der Arbeitsstrukturen. Trendreport Rationalisierung in der Automobilindustrie, im Werkzeugmaschinenbau und in der Chemische Industrie. Zwischenbericht. Göttingen: SOFI.

Schumann, M. (1998). "New Concepts of Production and Productivity." Economic and Industrial Democracy 19(1): 17-32.

Sisson, K. 1996. Closing the gap : ideas and practice : direct participation in organisational change. Dublin: European Foundation for the Improvement of Living and Working Conditions ; Luxembourg : Office for Official Publications of the European Communities.

Sitter, L. U. de. 1981. Op Weg Naar Nieuwe Fabrieken En Kantoren. Produktieorganisatie en arbeidsorganisatie op de tweesprong. Deventer: Kluwer.

Springer, R. 1999. Rückkehr zum Taylorismus? : Arbeitspolitik in der Automobilindustrie am Scheideweg. Frankfurt/Main ; New York: CampusVerl.

Taylor, F. W. 1911. "Shop Management.” in Scientific Management (1964). London: Harper and Row. 
Teulings, A. . 1977. Philips. Geschiedenis en praktijk van een Wereldconcern. Amsterdam: Van Gennep.

Vallas, S. P. 1999. "Rethinking Post-Fordism: The Meaning of Workplace Flexibility." Sociological Theory 17:78-101.

Womack, J., D. T. Jones, and D. Roos. 1990. The Machine that Changed the World: Based on the Massachusetts Institute of Technology \$5 million 5-year study on the future of the automobile. New York: Rawson.

Zuboff, S. 1988. In the Age of the Smart Machine. The Future of Work and Power. New York: Basic Books. 